\title{
FUNCTIONING OF PHI-CS (POLISH HARBORS INFORMATION\& CONTROL SYSTEM) AND THE SYSTEM FOR THE EXCHANGE OF INFORMATION AND SAFETY IN THE NATIONAL MARINE SAFETY SYSTEM
}

\section{Jolanta Martuszewska}

Polish Naval Academy, Faculty of Command and Naval Operations, Śmidowicza 69 Str., 81-127 Gdynia, Poland; e-mail: jolantahmartuszewska@gmail.com

\begin{abstract}
Increasing security in Polish maritime areas is not only a priority for maritime administration, but all users of this zone. The article proves the general assumptions of the implementation of the National Maritime Safety System as well and the method of implementation of its individual elements. Detailed system information was included PHI-CS and Information Exchange System and Sailing Safety. An attempt was made to investigate the scope of modernization of the System of Information and Navigation Safety System. The article describes elements: the national Safe Sea Net system, rules of passenger registration, databases, ICT connections.
\end{abstract}

Key words:

NMSS, Safe Sea Net system, PHI-CS, Information Exchange and Navigation Safety System.

Research article

(C) 2018 Jolanta Martuszewska This is an open access article licensed under the Creative Commons Attribution-NonCommercial-NoDerivatives 4.0 license (http://creativecommons.org/licenses/by-nc-nd/4.0/) 


\section{INTRODUCTION}

The key to an effective response to danger at sea is reliable, adequate, permanent and complete information, handed over in the shortest possible. This is a prerequisite for gaining an advantage that leads to stability and security in many aspects and areas of life. This situation also applies to the maritime safety area. Systems such as the System for the Exchange of Information and Safety and PHI-CS such existing within the framework of the regional and state navigation monitoring system are used at the strategic level by government institutions and agencies, mostly within the framework of the NMSS.

The article focuses on the presentation of the Safe Sea Net (SSN) information network based on the available AIS signal, the System for the Exchange of Information and Safety and PHI-CS systems addressed to users of shipping including applications supporting and optimizing operational processes. The maritime administration strives to ensure safety at sea as high as possible. On the basis of the Information Exchange System (SSN), it cooperates with the European Union member states and extends the maritime scope of its activities from the state to the European area.

The geographical location of Poland on Baltic Sea coast requires efficient security in its maritime area. T. Szubrycht states that the maritime safety of the state is a set of undertakings undertaken by the state to secure its interests in the open sea area, the exclusive economic zone, territorial and internal waters, and the coastal belt. The task of the Polish maritime administration, which has a territory of 32202.57 square kilometers under its jurisdiction, is safety management in sea areas.

The Polish maritime administration reports directly to the Ministry of Maritime Affairs, but it has no centralized structure and is divided into three parts managed separately by individual maritime offices: The Maritime Office in Gdynia, Słupsk and Szczecin. The director of the Maritime Office as an entity of the government's independent administration is subordinated to the relevant minister for maritime affairs, administering administration in maritime areas of the Republic of Poland.

The areas of maritime offices in Gdynia, Słupsk and Szczecin, and the Maritime Search and Rescue Service (SAR) include in particular approaches to ports, their redevelopment, anchorages and coastal zones (fig. 1). The Maritime Office in Gdynia is the project coordinator and contracting authority and performs its tasks based on the Agreement of 25 February 2010 between the Directors of Maritime Offices and the Maritime Search and Rescue Service. Each of the maritime offices has its managing own control center, which manages on its territory, while being 
subordinated to the National Maritime Safety Center located in Gdynia (fig. 2). Cooperation with national institutions and foreign institutions, in particular with counterparts in other EU countries, is successful for NMSS.

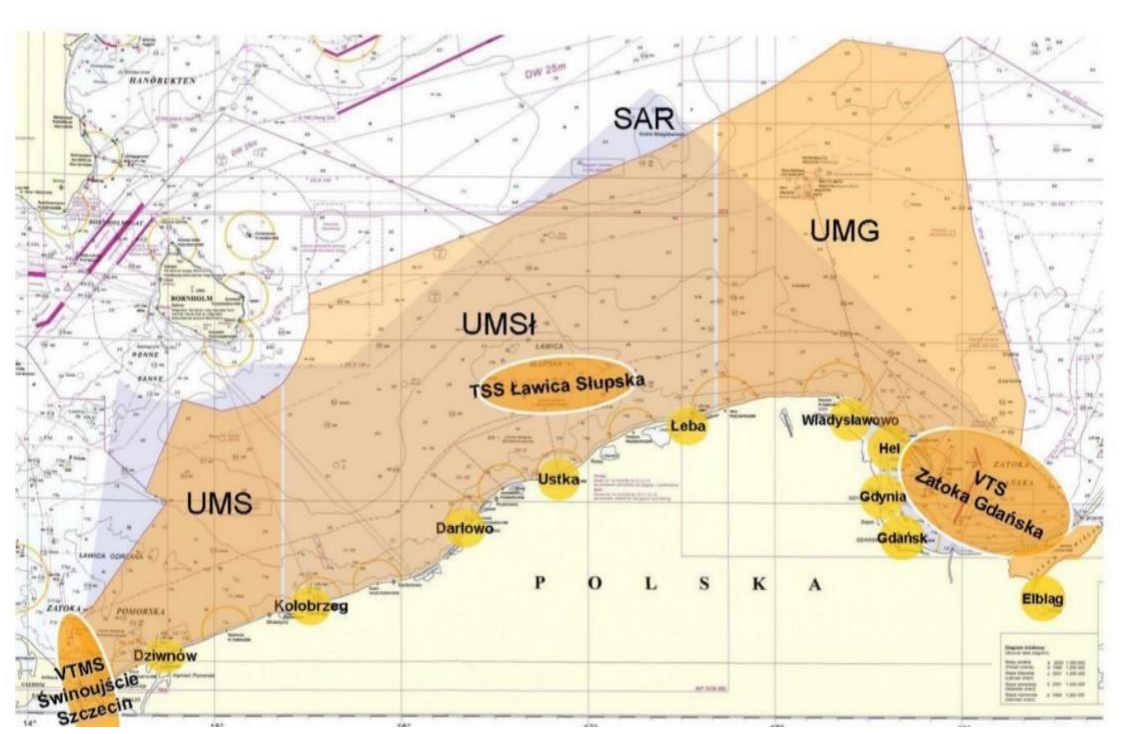

Fig. 1. Areas of activity of the NMSS services, the Maritime Office in Gdynia (UMG), the Maritime Office in Słupsk (UMSł) and the Maritime Office in Szczecin (UMS), VTS port captains, VTMIS and the area of operation of the Polish SAR service [5]

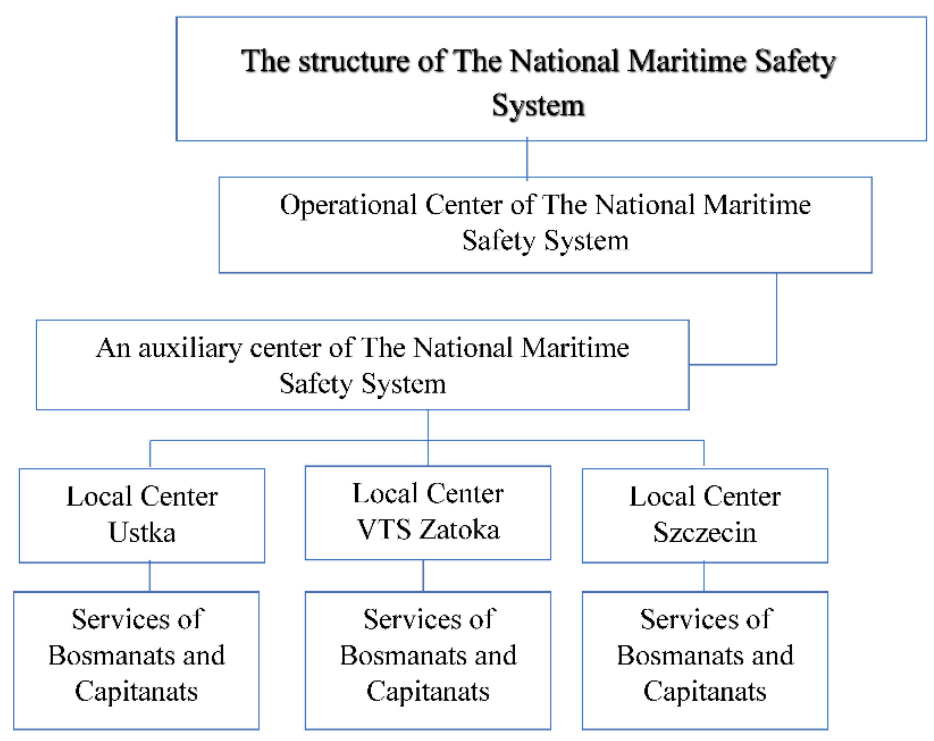

Fig. 2. Scheme of the National Maritime Safety System [2] 
Such structure distinguishes Poland from other European countries. The Polish maritime administration complies with the general provisions of the SOLAS 1974 Convention, so far there has not been a central security management system. The individual activities were carried out separately. A good example is the establishment in the Polish zone of shipping routes and ship traffic established directly on the approach to the port of Świnoujście and the Tricity ports, but in case of routes running south of the island of Bornholm (passage close to Sławska Bank, etc.), the problem has not been resolved to this day [1]. Moreover, in Poland the State Commission for the Investigation of Marine Accidents (PKBWM) was established in only 2012. Establishing GDPBWM is of strategic importance for maintaining a high level of maritime safety.

As part of the joint action of Poland and the EU, the legal requirements for setting up a maritime policy information exchange plan, include:

- action plan for the development of a European Border Surveillance System (EUROSUR), it provides setting up of a Joint Information Sharing Environment for the EU Marine Areas ('CISE Mechanism');

- community vessel and ship traffic information system was created (Directive 2009/17/EC amending Directive 2002/59/ECand 2011/15/EU of 23 February 2011);

- directive on reporting formalities for ships entering or leaving ports of Member States (Directive 2010/65/EU of 20 October 2010 and repealing Directive 2002/6/EC).

Activities related to new technical support systems and supervising shipping so far have also been carried out without coordination. For this reason, the European Commission has sought to establish a decentralized information system that connecting civil and military groups.

Polish maritime administration is implementing a project that helps to solve the issue of security management in Polish maritime areas. It is the construction of the National Maritime Safety System. The system is created to provide technical infrastructure, including purchase and installation of new elements and modernization of existing elements. Taking action that takes into account the latest practical and organizational solutions combined with European Union initiatives has an impact on a significant improvement in communication between activities and ensuring the safety of shipping. 


\section{NATIONAL MARITIME SAFETY SYSTEM (NMSS-I)}

Poland has been involved in the implementation of the integrated maritime policy The EU has set up an interministerial team for the Maritime Policy of the Republic of Poland as an advisory and consultative body for the Prime Minister, which prepared the strategic project 'Poland's maritime policy until 2020'. In 2009, the program document 'Assumptions of the Polish maritime policy until 2020' [11] was prepared on the integration of monitoring systems, maritime surveillance, civil integration, military surveillance and monitoring systems of maritime traffic. The project is implemented in two stages, the first (NMSS-I) is the construction of local infrastructure (completed), the second (NMSS-II) is the construction of a fiber-optic link along the coast and the Pomeranian Telecommunications (NMSS-IIA).

The purpose of the construction of the National Maritime Safety System, Stage I (NMSS-I) is to create a monitoring and control system for uniform security management in the maritime areas of the Republic of Poland, by the Maritime Administration and for the exchange of navigation safety information with the Naval Operational Services, the Maritime Department of the Border Guard (MOSG) and Provincial Crisis Management Centers (CZK) and other central and field services [3].

The mission of NMSS Stage I is an efficient exchange of information between entities involved in securing the proper organization of maritime traffic. The concept of the most modern systems assumes the transmission of data by electronic means. From the point of view of the NMSS system, building a backbone network based on the existing infrastructure of Maritime Offices, SAR Service, Border Guard and Navy assumes: improving the safety of navigation in the areas covered by the maritime traffic monitoring system:

- improving the safety of navigation in the areas covered by the maritime traffic monitoring system;

- supporting ship traffic control services (VTS) in making appropriate decisions related to the organization and efficiency of maritime traffic;

- ensuring the early and efficient collection and exchange of information, especially regarding the protection of ships and seaports;

- using the Automatic Ship Identification System (AIS) to the best extent possible, especially with regard to information received from ships by shore stations of the system;

- cooperation of the services of individual centers, especially in the field of safety and protection of shipping, saving life at sea and protection of the marine environment;

3 (214) 2018 
- cooperation of the services of individual centers, especially in the field of monitoring the carriage by sea of passengers, dangerous or polluting goods [5].

NMSS acts as one of three systems operating in Poland to ensure maritime safety. It is worth mentioning here the integrated Border Guard surveillance system, the 'Łeba' Naval System for monitoring shipping in Polish maritime areas, which also works with similar systems of the European Union and with the NATO defense system. KBSM is divided into three subsystems [12]:

1. Maritime Surveillance and Maritime Safety Monitoring Subsystem (SMRM). Its operation consists of using full (source) data from sensors. At the level of local traffic services (Harbor Master's and VTS departments), the basic source of data for creating a picture of the situation at sea and situation assessment is to be received from the installed sensors. As part of the radar subsystem below networks are included:

- long-range radars;

- short-range (port) radars;

- Vessel Traffic Services (VTS) radars and Vessel Traffic Management System (VTMS) radars;

- CCTV systems;

- the Vessel Monitoring System (VMS) subsystem;

- meteo sensors.

NMSS observes the navigational situation on a real time by means of local traffic control centers and uses the collected and processed information at the central level in order to address threats and early identification of dangerous events. The source data from the sensors is transmitted to the centers via a local network owned by maritime offices. Radar data and AIS data are subject to multi-tracking. The user interface in VTS centers are workstations equipped with map applications (traffic management), database, recording, playback and communication systems. Port Harbor Master's traffic services have work stations of the proper VTS system. In the event of a transmission network failure or unavailability of VTS centers, Harbor Master's have independent access to information from their own (local) sensors. Images from installed cameras are available on monitors in VTS and Master centers.

The camera data recording is carried out locally. The transmission of processed data from sensors and VTS databases is carried out via the WAN to the central system application. The NMSS's central information application is provided by the Shipping Safety Information Exchange System. The central application is used to enter data 
streams from the Automated Radar Surveillance System (ARS) system (KOSN Comprehensive Naval Situation Picture) and from other external sources to have most accurate data of the observed area.

2. The vessel tracking and identification subsystem created from the connection to:

- subsystem of the National Network of Base Stations of the Automatic Identification of Ships System (AIS-PL);

- shoreline stations of the Automatic Identification System AIS, Termination;

- Long Range Identification and Tracking System (LRIT);

- DGPS Maritime Network (implemented) of the DGPS-PL reference station system (Differential Global Positioning System).

3. Early Warning System (EWS) for Polish sea basins created from:

- data exchange with the EU (Safe Sea Net);

- GMDSS communication;

- Maritime Assistance Services (MAS);

- SAR search and rescue services;

- Ship Reporting Systems (SRS);

- networks of hydrometeorological, coast and sea stations;

- Traffic Separation Schemes (TSSs).

The System for the Exchange of Information and Safety system, as the NMSS central application, serves as a 'Single Window' for state services performing tasks in the maritime safety area in particular of navigation and protection of the marine environment safety [5]. It is important that the subsystems are compatible and able to cooperate with each other in the shortest time possible to efficiently ensure, maintain and control the safety of vessels at sea.

NMSS stage-I is completed. The European Union requirements regarding the construction of NMSS have contributed to the polish maritime administration and SAR in a unified system enabling control of maritime safety. This system is based on the latest technological devices, and its structure ensures high operational reliability thanks to redundancy and parallel data transmissions.

\section{NATIONAL MARITIME SAFETY SYSTEM (NMSS-II)}

In the second stage of NMSS implementation, the Polish Baltic coast will be equipped with a modern communication system in its entirety and extent. From Hel 
to Świnoujście, an optical fiber forming the so-called Pomeranian Telecommunications Line (fig. 3) was laid. This will ensure the integration of outlets with already existing fiber-optic links in the relation Szczecin-Świnoujście and Gdańsk — Gdynia. Continuous communication of all local maritime administration bodies and SAR services will enable, among other things, data transmission as a part of the Maritime Monitoring and Maritime Security Monitoring System (MM\&MSMS) and remote service of its sensors [5].

As part of the implementation of the Pomeranian Telecommunication, construction is planned (NMSS-IIA) [7]:

- tele technical sewage network core made of three RHDPE pipes $\varnothing 40 / 3.7$ and one pipe with prefabricated RHDPE micro-sewer $\emptyset 40+7$ x 10 mm with making wells and cable trays;

- tele technical sewage system for end points remote from the main optical fiber axis made of two RHDPE $\emptyset 40 / 3.7$ pipes;

- fiber optic cable with a capacity of 144 fibers arranged in a built telecommunication duct for the needs of the core of the network;

- fiber optic cable with a capacity of 24 fibers arranged in a built telecommunication duct for the needs of connections to end points;

- undersea fiber optic cable with a minimum capacity of 144 fibers arranged on the Gdynia - Hel section;

- construction of network nodes (equipment containers);

- installation of node equipment components, CCTV, SSWiN, Access control, monitoring of climatic conditions, extinguishing systems, cooling systems;

- installation of endpoint equipment;

- installation of power generators and UPSs;

- installation of active network devices for implementation;

- equipping a Management Center with management and monitoring infrastructure [3].

Better communication between ports, coordinated by employees and navigators from Maritime Offices will improve their patency, which in turn will enhance to the competitiveness of Polish ports. The use of the Pomeranian Telecommunications by maritime administration units will increase the possibility of creating new, better logistics and organizational solutions, which will facilitate the development of 'motorways of the sea' and the Trans-European Transport Network TEN-T in the future. 


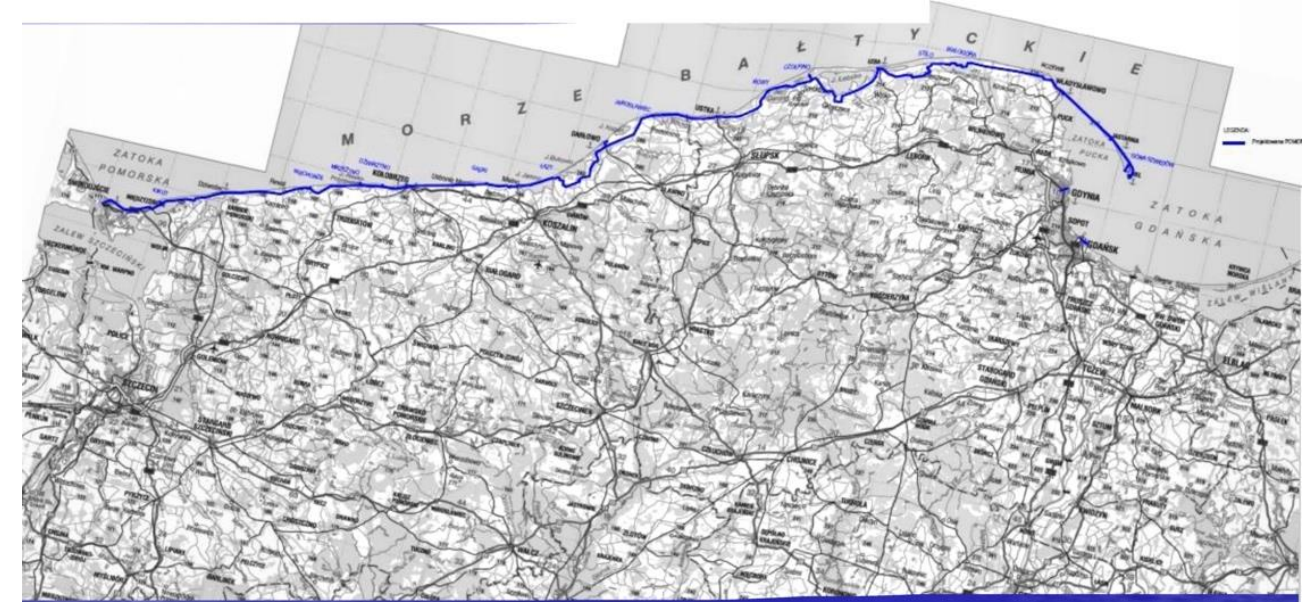

Fig. 3. Map of the course of the Pomeranian Teleinformation Bus [5]

The main goal of the Pomeranian Teleinformation Bus is to provide links with adequate capacity for NMSS and the Automated Radar Surveillance System (ZSRN) of Polish sea areas. The Pomeranian Teleinformation Bus already has $150 \mathrm{~km}$ of fiber-optic relations already while its target length will be over $600 \mathrm{~km}$ and $21 \mathrm{~km}$ of submarine cables ( $40 \mathrm{~km}$ in total).

In addition, the bus is to provide a fast and secure connection for the needs of the organizational units of the Ministry of Transport, Construction and Maritime Economy (Maritime Offices in Gdynia, Szczecin and Słupsk, and the Maritime Search and Rescue Service), the Ministry of the Interior (Border Guard) and the Ministry of National Defense (Polish Navy). Information of strategic network allows importance for maritime safety to be safely transmitted between individual units. The effect of these possibilities will be to improve access to key information of maritime safety point of view for services responsible for traffic monitoring, protection of rescue operations, prevention of marine accidents, and in addition will reduce the risk of ecological disaster.

\section{SAFE SEA NET SYSTEM (SSN)}

The European Marine Information Exchange System (Safe Sea Net) enables the reception, storage, retrieval and exchange of information to ensure maritime safety, port security, protection of the marine environment and efficiency of maritime transport. System users are:

- competent national authorities (NCAs) that have overall responsibility for national systems and grant access rights to domestic users; 
- local competent authorities (LCA), which are the authorities designated by Member States to receive, provide information based on SSN legal acts (e.g. port authorities, VTS naval rescue coordination centers (MRCC), and border guards, service, owners, agents ship, inspectors and others: authorized state services, etc.;

- other users: other EU bodies and institutions interested in the maritime state can apply for SSN status based on a pilot project.

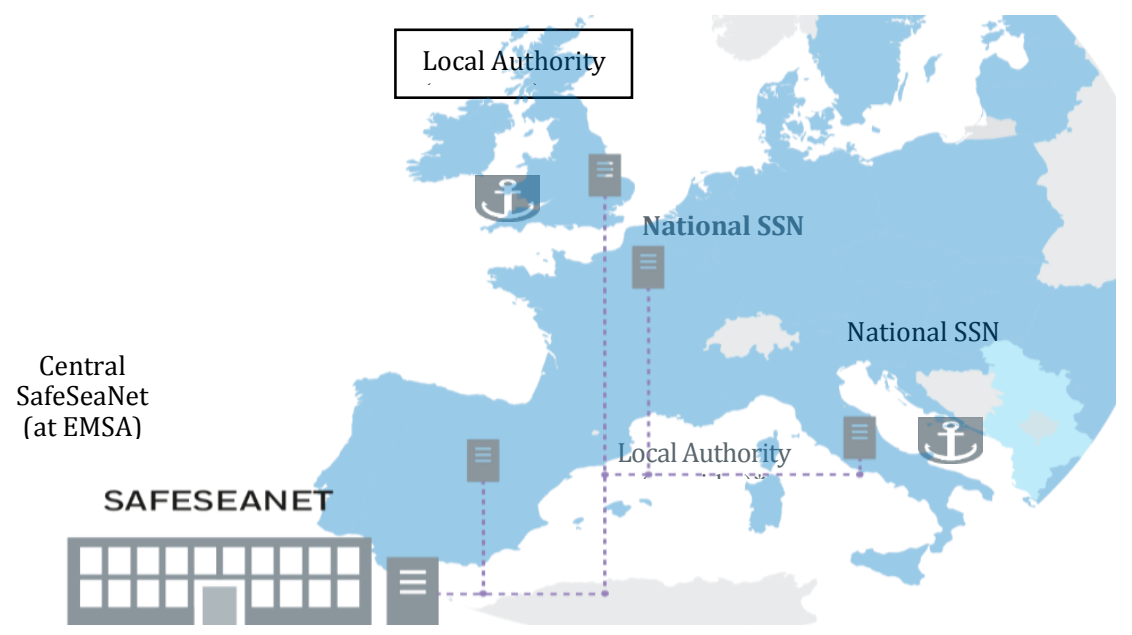

Fig. 4. Message-based mechanism [22]

SSN has been developed and implemented by the European Maritime Safety Agency (EMSA) within the SafeSeaNet group.

1. EU Commission: retaining overall responsibility (Management and Policy) for the central SSN system in cooperation with Member States.

2. Ember States: SSN, act as data providers, and are owners of their data.

3. EMSA: responsible for the Central SSN development, operation and maintenance of cooperation with MSs and Commission. EMSA supports the central SafeSeaNet system in a 24-hour mode and monitors its operation and data quality.

States. Issues regarding the overall data flow. Reports are a useful tool for assessing technical implementation. The directives in the Member States contain general information on the exchange of data via data flows from national systems to the central Safe Sea Net system [8]. Exchange information takes place through:

- sip positions from Authomatic Identification System (AIS) and MRS;

- call information;

- 24 hours pre-arrival information;

- 72 hours pre-arrival information (for PSL inspection);

- arrivals (ATA) and Departures (ATD). 
At the same time, EMSA has the ability to observe and respond to marine pollution throught SSN system, including warnings on oil spills in the Member States, rapid delivery of available satellite images and excellent situation in the field of crude oil (Clean Sea Net) Information on cargo residues, as well as ship-generated waste, information on redundancies, details of compensation for regular connections between ports on their territory, which are not obliged to prepare a report on 24-hour port.

Hazamat provides information on the transport of hazardous waste and marine pollution. It collects preliminary information about waste from cargoes and products produced by ships. In this way, it contributes to the creation of an effective coastline protection system and EU waters against pollution caused by ships. The Safe Sea Net also contains information on vessels released on their territory from regular connections between ports. Ships are required to report a 24-hour port report. In this way, it contributes to the creation of an effective system for protecting the coasts and EU waters against pollution.

When accessing Safe Sea Net, the first important thing is the web interface. It is a map based-graphical interface (Graphical Interface System-GIS) which makes the system user-friendly. Users have the possibillity to zoom in and out to display the images from the EU level to individual guays in ports. They can also view historical vessel positions and obtain selected information about ships in a number of different ways. The data is presented on high-quality nautical charts containing a number of useful marine information (fig. 5).

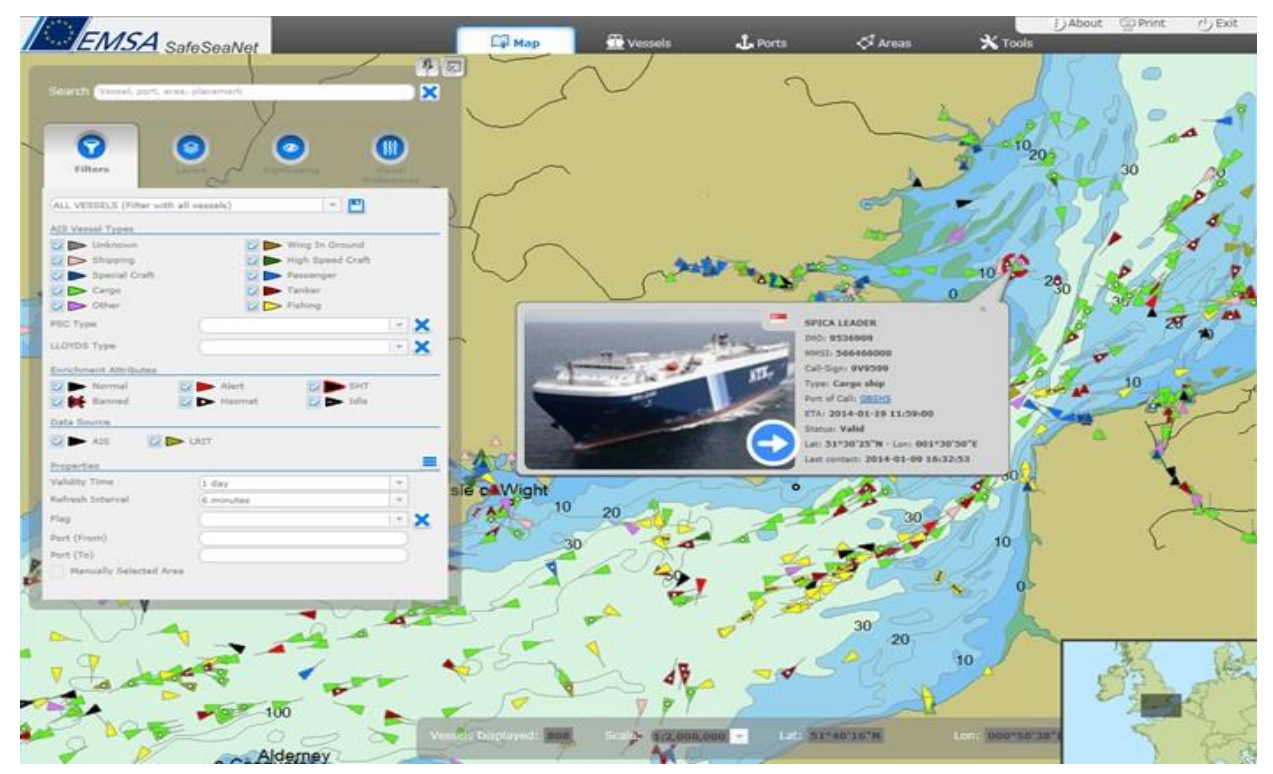

Fig. 5. Safe Sea Net graphical interface [6] 
He bases of the Safe Sea Net system is EIS (European Index Server). It works as a secure and reliable index system in the hub and spoke network. The authentication server checks the validity of data transfer and login. Sends requests and receives notifications and replies from approved users. Users can provide or search for data.

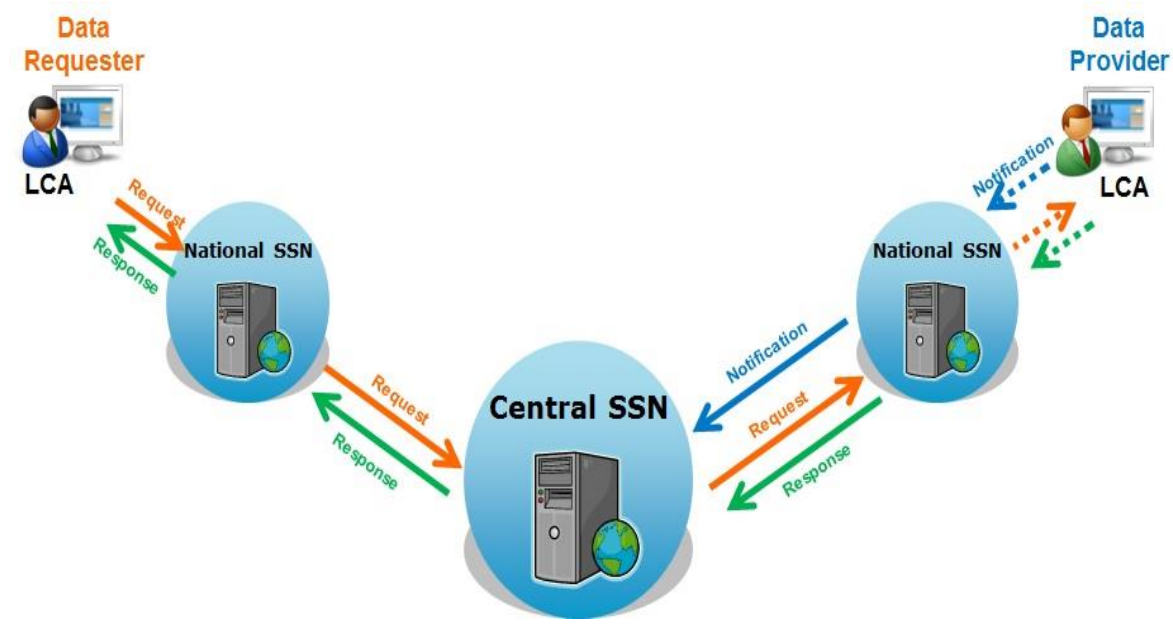

Fig. 6. Safe Sea Net system — information exchange [24]

The EIS system retrieves and retrieves information on related ships with one Member State in response to an inquiry or request from another entity. The information exchanged is very extensive, while the main applications include:

1. Ship notifications: to ensure a safe sea route with information about the cruise and cargo; notifications are based on two types of messages:

Automatic Identification System (AIS) messages are automatically sent by ships through very high frequency (VHF) radio signals and received by coastal stations within range. Mandatory Ship Reporting Systems (MRS) may be established by governments, with the consent of the International Maritime Organization, for certain types of ships passing through specific areas.

MRS messages are sent by ship captains to coastal stations. The information includes vessel identification, course, speed and load.

2. Port notifications: on arrival of ships and departure from ports. The approximate time of arrival, the actual time of arrival, the actual time of departure and the number of persons on board are included in the news.

3. Hazmat notifications: on the shipment of hazardous materials by ships on board (dangerous or polluting), the data provider has detailed information on these goods. 
4. Information provided by Member States on accidents and incidents occurring at sea. They can be associated with the safety of the ship and its seaworthiness (e.g. SITREP: safety and seagoing capacity of the ship), etc.

The national systems of all 24 coastal Member States as well as Slovakia, the Czech Republic, Austria and Hungary are connected to the central Safe Sea Net system. EMSA provides information from the EU LRIT Joint Data Center, ensuring the identification and tracking of ships flying the EU flag around the world.

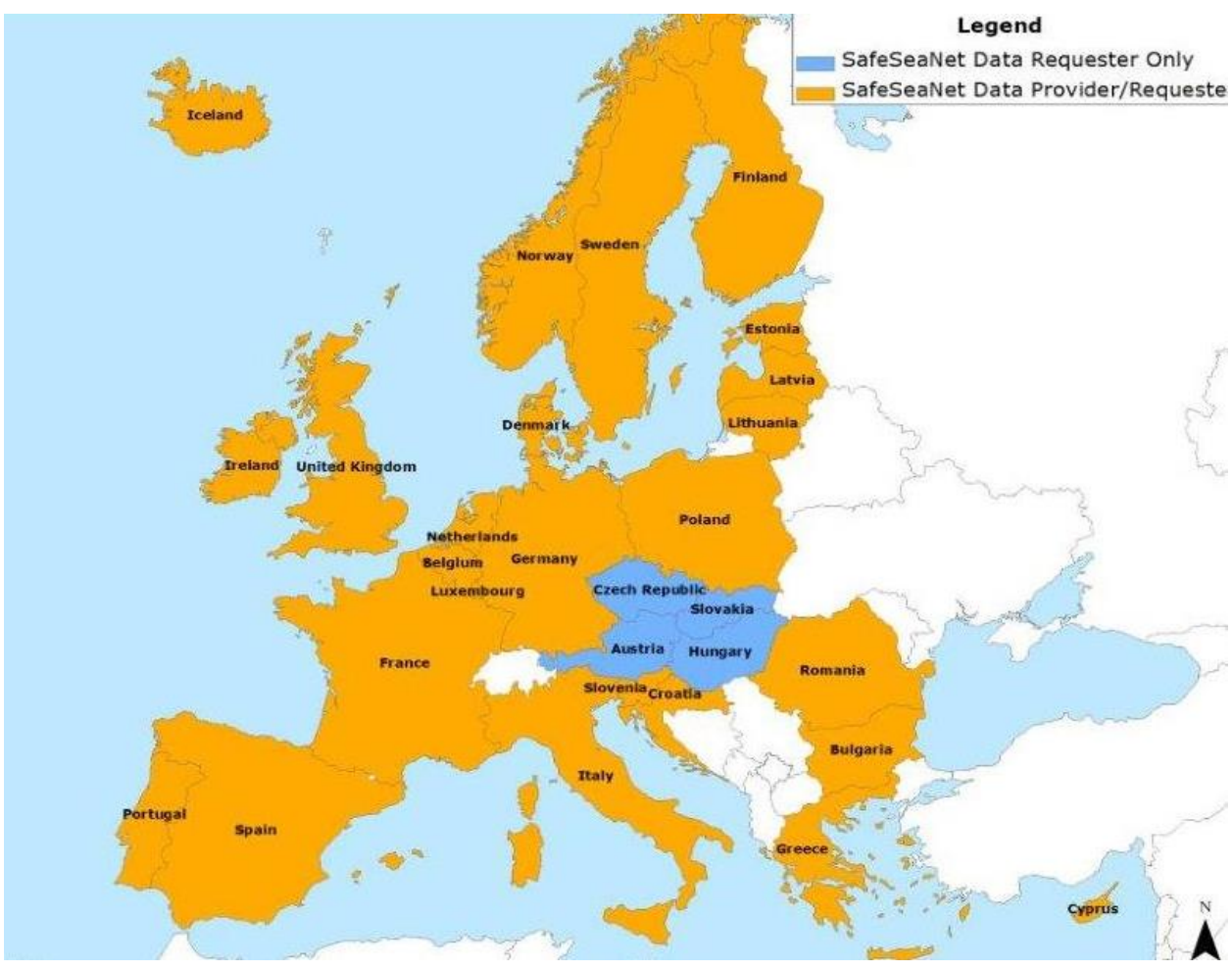

Fig. 7. Countries Participating in SafeSeaNet [8]

Further development of the Safe Sea Net system will increase the efficiency of data exchange and create opportunities for more comprehensive monitoring, and even closer cooperation between authorities. A concrete example of such an evolution is the concept of the Blue Belt and its pilot project, which aims to improve transport within the EU by minimizing administrative formalities. The main element of this concept is the use of existing maritime transport monitoring capabilities, in particular the Safe Sea Net system. 
The integrated maritime surveillance initiative under the integrated maritime policy aims to create a common environment for the exchange of information through the interconnection of user communities, including armed forces. The Safe Sea Net system plays a key role in this multinational initiative, providing access to data from the maritime transport sector. Safe Sea Net allows secure data transfer. It enables proper planning and supervision of maritime transport. In Poland, as part of this system, there are two systems: The Shipping Safety Information System and the Information System about Ports and Loads.

\section{PORT AND LOAD INFORMATION SYSTEM (POLISH HARBOR INFORMATION \& CONTROL SYSTEM - PHI-CS)}

The Polish Harbour Information \& Control System (PHI-CS) was created as a result of the so-called twinning agreement, concluded between the governments of Poland and Great Britain in order to adapt the standards of functioning of the Polish maritime administration services to the applicable standards in the EU Member States, PHI-CS has been modernized and expanded several times.

PHI-CS provides electronic data registration and enables document exchange (Directive of European Parliament and Council 2002/59/EC of June 27, 2002). The main PHI-CS server collects and segregates the necessary data for effective search and rescue (SAR). The collected information is important for the speed of rescue operations and the assessment of ecological threats related to the transport of dangerous cargo by sea. PHI-CS allows, among others for coordinated registration and registration of revolving passenger units, units transporting hazardous materials and for fast exchange of information on the results of inspection of the Port Control of Ships (PSC), detentions, prohibitions on entering ports or on passengers on board who succumbed to an accident after leaving the Polish port.). It also allows quick verification of seamen's qualifications documents issued in individual maritime offices. Data for the system is entered by maritime offices, as well as by ship owners, their owners, captains and agents and shippers. The communication of external users (agents, ships, shippers) with the system is carried out using the Internet network.

The Polish maritime administration monitors and also controls and supervises the issuing of seafarers' documents regarding ships (certificates and security cards). The system user is the Ministry responsible for maritime economy, maritime offices (Szczecin, Gdynia, Słupsk), Maritime Search and Rescue Service (SAR) as well as the Customs Service and the State Border Guard [22]. 


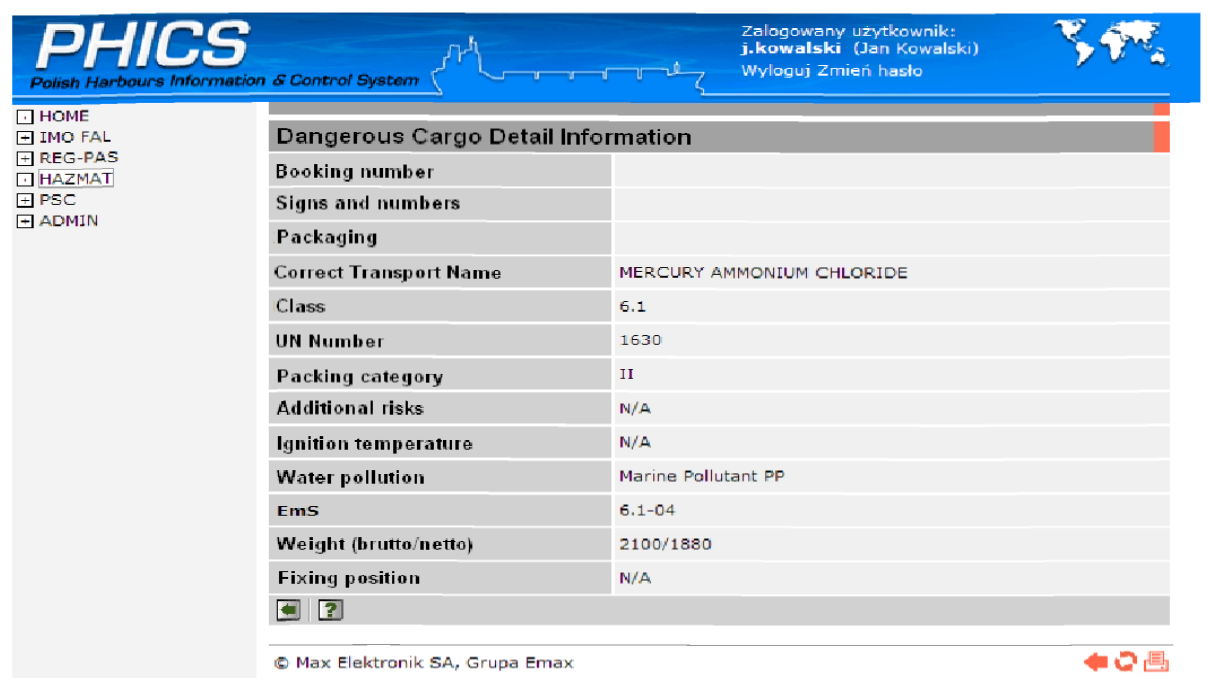

Fig. 8. Information about hazardous cargo in Hazamat subsystem [18]

The PHI-CS structure (fig. 9) contains five databases (subsystems):

- control of ship calls at Polish ports (IMO FAL);

- registration of passengers (PAS-REG) which ships to ships in Polish seaports, in accordance with with the requirements of Council Directive 98/41/EC of 18 June 1998 on the registration of persons sailing on board passenger ships operating to or from ports of the Member States of the Community;

- monitoring sea traffic of ships carrying dangerous or polluting goods (HAZMAT);

- inspection on foreign ships flagged in Polish ports by port state inspection (PSC);

- qualification documents for seafarers and certificates for navigation and seafarers (STCW).

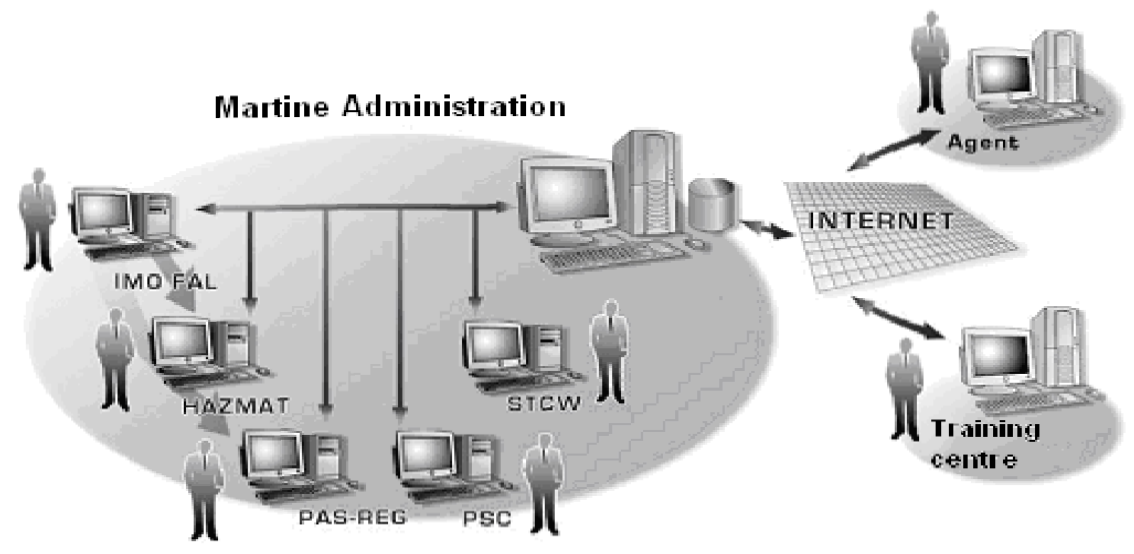

Fig. 9. Architecture of the PHI-CS System [22] 
An important factor is the time of providing information for efficient maintenance and controlling the safety of vessels at sea. Due to the increase in the number of data transmissions, and the increase in the number of PHI-CS system users, constant surveillance of the operational infrastructure is important. In order to maintain a fast transfer of information through PHI-CS, a check is necessary to ensure correct handling.

\section{SHIPPING SAFETY INFORMATION EXCHANGE SYSTEM}

The System for the Exchange of Information and Safety (Shipping Safety Information Exchange System) was created by Sprint SA for the needs of the Maritime Office in Gdynia. In the early years of use, it served as a platform for the distribution of information between the cooperating operational services in the area of maritime safety protection: The Maritime Office in Gdynia, the Polish Naval Operations Center of the Polish Navy, the National Navigation Coordinator Office of the Hydrographic Bureau of the Polish Navy (BHMW) and Radiolocation Center of the Maritime Border Guard Unit. In subsequent years, the system was extended to include new users, including Maritime Offices in Szczecin and Słupsk, SAR Service, Provincial Crisis Management Centers (coordinating the activities of, among others, the Police and Fire Brigade), the Maritime Mobile Group of the Customs Chamber as well as harbor masters and various cells organizational offices entities of the sea. The system also uses information provided, among others, by: Institute of Meteorology and Water Management, European Safe Sea Net system, VTS Gulf Gdańsk system, AIS system and Lloyd's Registry of Shipping [9].

Shipping Safety Information Exchange System is one of the oldest systems of this type in Europe and is based on the Vizan software. The System for the Exchange of Information and Safety through a teleinformation network (fig. 10) is used to organize the exchange of information on threats (Act of 4 September 2008 on the protection of shipping and seaports and the International Code for the protection of a ship and a port facility - ISPS Code). Its important task is to send information between operational services cooperating in the field of maritime safety protection and selected entities with appropriate terminals. The most important tasks that the system implements include the collection and use of information on:

- ship traffic in Polish;

- maritime areas;

- transport of dangerous cargo by sea; 
- violations of security zones, including marine polygons;

- saving life at sea;

- protection of the marine environment;

- other potentially dangerous situations in maritime traffic [19].

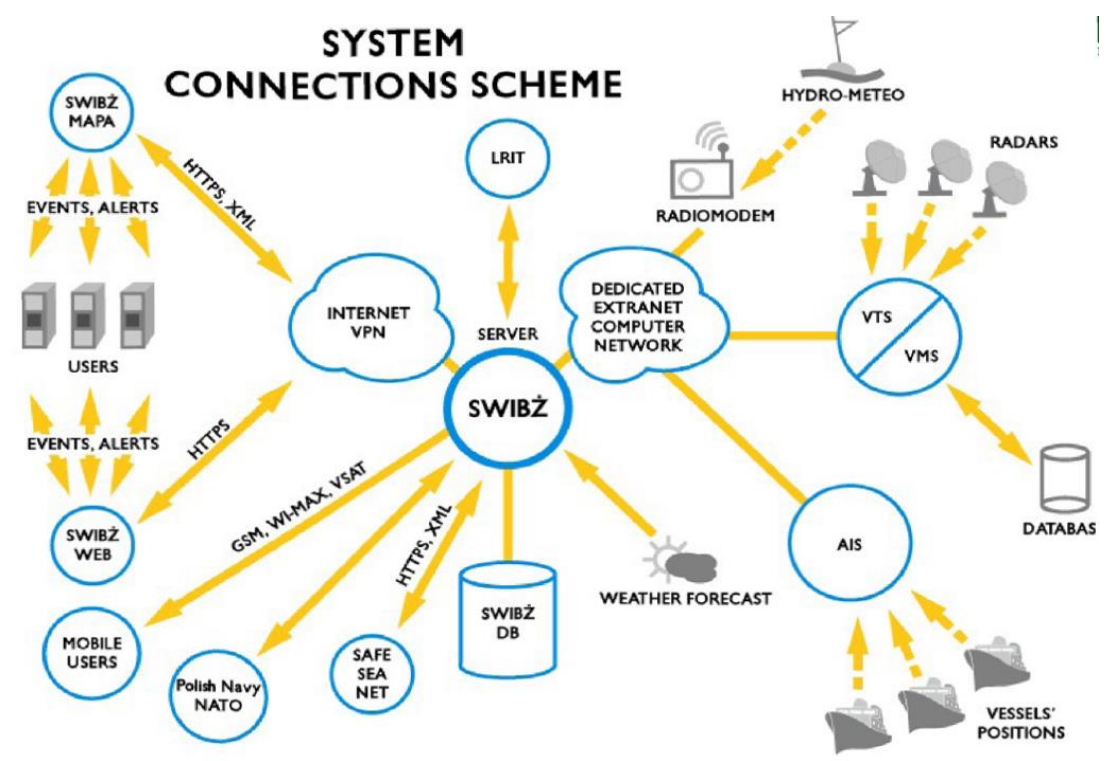

Fig. 10. Shipping Safety Information Exchange System connections schemme [21]

Shipping Safety Information Exchange System also uses electronic systems for the administration of sea members of the European Union and institutions cooperating to monitor ship traffic (for example, the system acts as a national information exchange center-National Contact Point from Safe Sea Net-EMSA) and automatic exchange of information on the current navigational situation in EU waters, early warning of potential threats and support for rescue operations and ship crisis and port security.

The system uses the following data sources [19]:

- information from the European Safe Sea Net system;

- AIS stream from Baltic and world coast stations and from the satellite source AIS;

- data from the VTS Gulf of Gdańsk system;

- information from the Lloyd Ship Register;

- navigational warnings and Nautical messages originating from the BHMW;

- weather forecasts developed at IMGW;

- applications received directly by operators of individual services;

- hydro-meteo data from automatic sensors;

- data from radar systems.

3 (214) 2018 
The Shipping Safety Information Exchange System application is based on a map display (compliant with the IHO S-52 standard), covering Polish sea areas and terrestrial areas within the responsibility of directors of individual maritime offices, as well as the entire Baltic Sea basin. The display uses map cells (fig. 11) in the S-57 standard obtained from BHMW and enables placing additional operational information in a layered system.

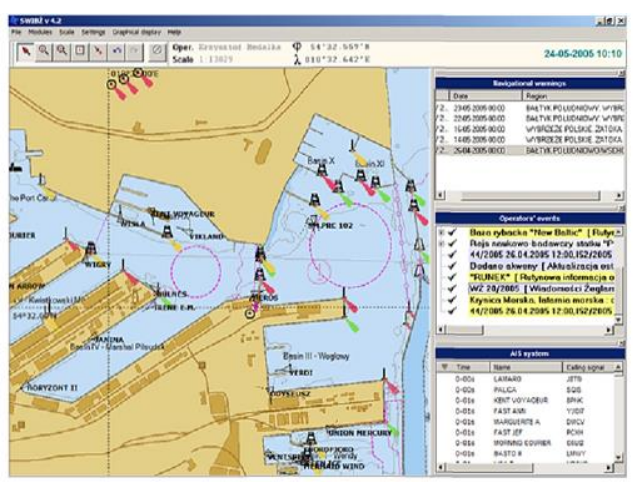

Base map AIS

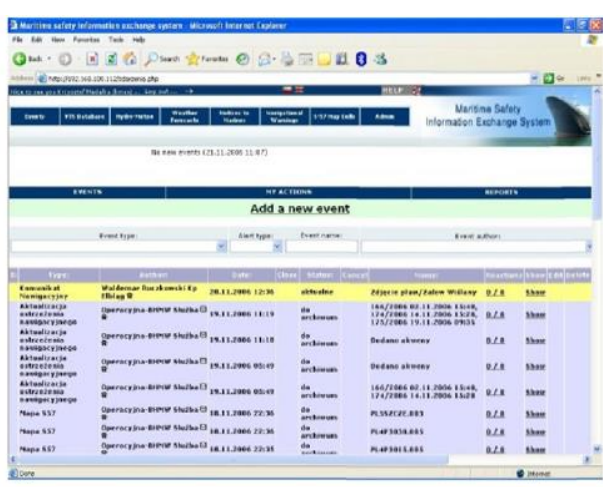

Program database the System for the Exchange of Information and Safety

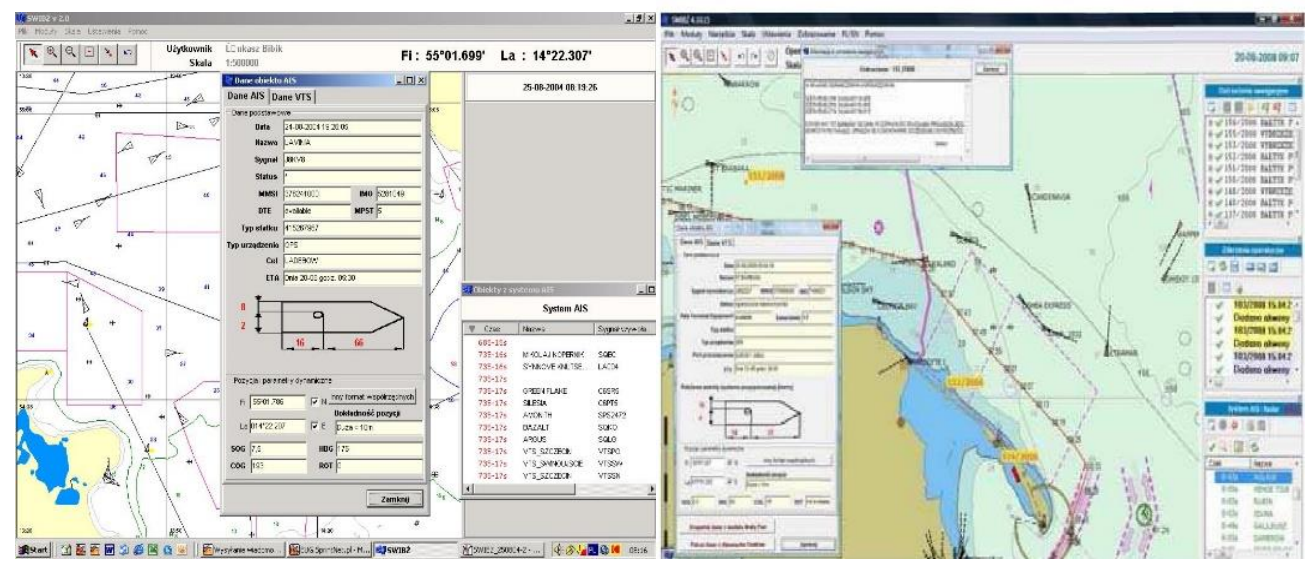

Fig. 11. Map display of the System for the Exchange of Information and Safety program [6]

The figure shows the system and software based on the information stream from the AIS (Authomatic Identification tabs - and the PHI-CS subsystem).

One of the morphological elements of the System for the Exchange of Information and Safety system is the system (subsystem) of VTS Zatoka Gdańska. All information presented in the map display is stored in the system database. Generating data on the map automatically saves them in the database part and vice versa. 


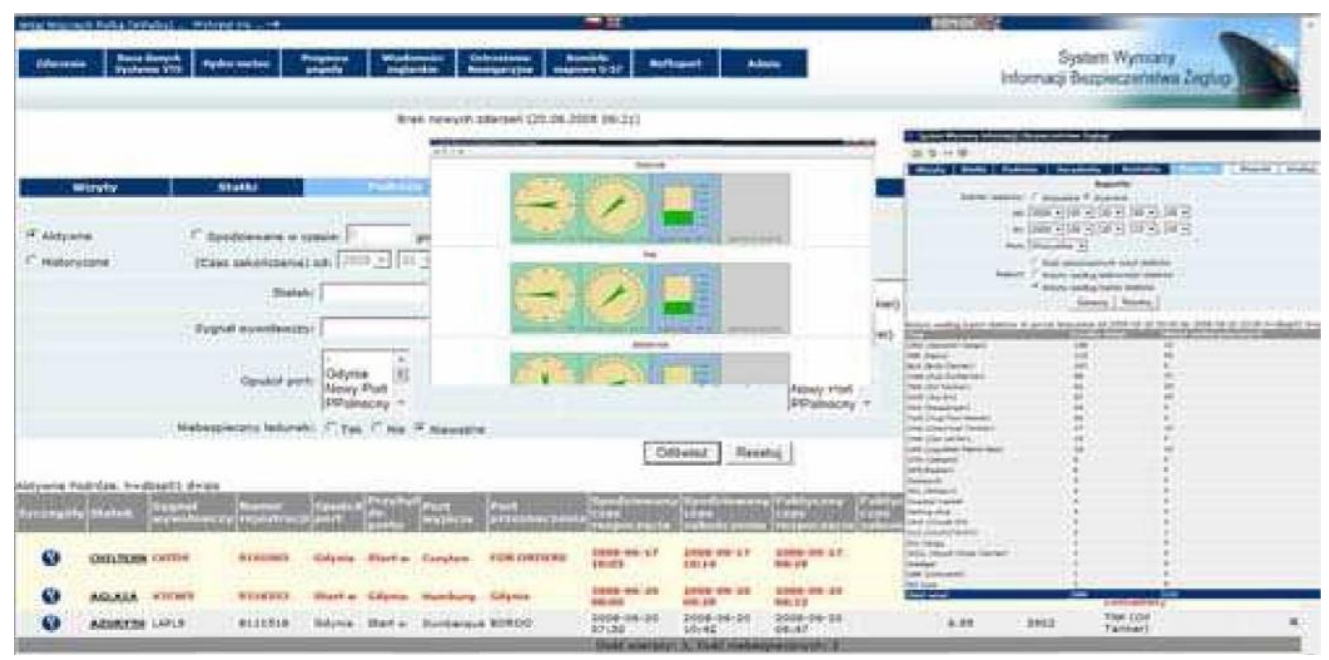

Fig. 12. Map display the System for the Exchange of Information and Safety in the information exchange [6]

Thanks to the interactive cooperation of the map display with the event generation system (information packages) [6]:

- calling event information allows automatic presentation of the attached graphical layer;

- selection of the object presented on the indicator enables generation of an event directly related to this object;

- the user has the opportunity to use the library of objects; the given call causes displaying or highlighting the selected object in the display;

- the map has the ability to visualize the vessel traffic based on information from the AIS system.

The System for the Exchange of Information and Safety system as a distribution platform collects, classifies and exchanges information via an IT network (Extranet). The program operator defines types of events, introduces procedures related to their operation, including a list of persons or institutions that should be immediately notified about the occurrence of an event. New events can be initiated by operators ('manually') or automatically - thanks to the analysis of data sent to the server from sensors placed 'in the field' or information obtained from other systems or databases.

Thanks to the development of NMSS, the range of the System for the Exchange of Information and Safety operations has increased by new offices and institutions. New cooperation opportunities have opened, and more system development needs have appeared to be able to efficiently monitor the maintenance of maritime 
safety. Increase the number of transfers and data processing and the number of users of the System for the Exchange of Information and Safety system requires its constant modernization.

\section{CONCLUSIONS}

The development of information technologies accelerates the processes of digitizing information exchange, transmission of Safe Sea Net network data, due to its nature, global coverage and the important role of fast information transfer. Ship traffic at sea is an area of implementation of the most modern solutions in the field of IT, which include information systems on ports and loads (PHI-CS), maritime safety information exchange systems. The systems presented in the study are used in NMSS and constitute its essential element.

In order to meet the growing demand for new solutions in the field of maritime traffic safety, it is necessary to ensure their efficient operation and constant modernization. Having reliable, adequate, permanent and full information in real time is necessary in order to maintain stability and safety in vessel traffic. The use of systems is a guarantee of the highest level of safety in the event of marine accidents, pollution of the marine environment, and terrorist threats.

Safe Sea Net information systems, constantly growing scope of its operations, new challenges such as and the emerging restrictions require new innovative solutions. The technological revolution has created new possibilities, it also reduced the related costs to a large extent with the implementation of even the most technically advanced applications and systems. Innovative solutions bring many benefits to both maritime administration and maritime traffic users. An example is the information exchange systems the System for the Exchange of Information and Safety, PHI-CS presented in the article, their use in a significant way contributes to the solution of many important and difficult problems related to the movement of ships, their security and efficiency of logistic processes.

\section{REFERENCES}

[1] Jagniszczak I., Bezpieczeństwo transportu wodnego, [in:] Zintegrowany system bezpieczeństwa morskiego, Part 1, ed. R. Krystek, Gdańsk University of Technology, Gdańsk 2009 [Safety of water transport, in: Integrated maritime safety system — available in Polish].

[2] Kopacz Z., Morgaś W., Krajowy system bezpieczeństwa morskiego w zintegrowanej polityce Unii Europejskiej, 'Zeszyty Naukowe AMW' [Sciencific Journal of PNA'], 2011, No. 2, pp. 65-76 [National Maritime Secutity System in EU integrated policy — available in Polish]. 
[3] Krajowy System Bezpieczeństwa Morskiego. Etap I, [online], http://www.umgdy.gov.pl/?p=8741 [access 04.04.2018], [The National Maritime Safety System. Stage I — available in Polish].

[4] Krajowy System Bezpieczeństwa Morskiego. Etap II, [online], http://www.umgdy.gov.pl [access 04.03.2018, [The National Maritime Safety System. Stage II — available in Polish].

[5] Królikowski A., Kierzkowska M., Globalne problemy zwiqzane z bezpieczeństwem w wybranych sektorach przemysłu morskiego, Conference 'Od szkolenia do sektora żeglowania' ['From training to the sailing sector', PZŻ, Gdynia 2015, [online], https://docplayer.pl/ 17659638Globalne-problemy-zwiazane-z-bezpieczenstwem-w-wybranych-sektorach-przemyslu-morskiegodr-inz-kpt-z-w-andrzej-krolikowski-magdalena-kierzkowska.html [access 17.04.2018], [Global security problems in selected sectors of the maritime industry — available in Polish].

[6] Królikowski A., Stupak T., Wawruch R., System bezpieczeństwa morskiego na polskich wodach morskich, [in:] 'Logistyka', ILIM, 2015, No 4 [The maritime safety system in Polish sea waters available in Polish].

[7] Leksykon bezpieczeństwa morskiego, ed. T. Szubrycht, C.H. Beck, Warszawa 2016 [The lexicon of maritime security — available in Polish].

[8] Sprawozdanie oceniajq̨ce wdrożenie i skutki środków podjętych zgodnie z dyrektywq 2002/59/WE ustanawiającq wspólnotowy system monitorowania i informacji o ruchu statków, European Commission, Brussels, 05.04.2018 [Report assessing the implementation and impact of measures taken in accordance with Directive 2002/59/EC establishing a Community vessel traffic monitoring and information system - available in Polish].

[9] Stupak T., Wawruch R., Utilisation of the databases for maritime safety control, 'Transport System Telematics', November 2008.

[10] The Marine Spillage Visualization \& Forecasting. Marsseis module, [online], www.sprint.pl [access 07.04.2018].

[11] Ustawa z dnia 23 stycznia 2009 r. o wojewodzie i administracji rzq̨dowej w województwie, art. 56, ust. 1, pkt. 8 [Act of 23 January 2009 on the voivode and government administration in the voivodship, art. 56, sec. 1, point 8 - available in Polish].

[12] Wąż M., Nowak D., Praczyk T., Accuracy analysis of maneuver performance in relation to moving object, 10th International Conference 'Computer Systems Aided Science Industry and Transport Proceedings', Zakopane 2006.

[13] Założenia polityki morskiej Rzeczypospolitej Polskiej do roku 2020, Ministerstwo Infrastruktury [Ministry of Infrastructure], Warszawa 2009 [Assumptions of the maritime policy of the Republic of Poland until 2020 - available in Polish].

[14] Zamówienia projektu 'Krajowy System Bezpieczeństwa Morskiego. Etap I', [online], www.umgdy.gov.pl [access 04.04.2018], [Project orders 'National Maritime Safety System. Stage I' — available in Polish].

[15] Zaprojektowanie i budowa Pomorskiej Magistrali Telekomunikacyjnej - Krajowy System Bezpieczeństwa Morskiego (KSBM), etap II A, [online], http://www.umgdy.gov.pl/?p=8692, [access 01.03.2018] [Design and construction of the Pomeranian Telecommunications Bus National Maritime Safety System (KSBM), stage II A — available in Polish].

[16] Zintegrowany system bezpieczeństwa transportu, Part 1, Diagnoza bezpieczeństwa transportu w Polsce, University of Technology, Gdańsk 2009 [Integrated Transport Safety System. Diagnosis of transport safety in Poland - available in Polish]. 
[17] http://emsa.europa.eu [access 05.04.2018].

[18] http://mib.gov.pl/2-TENT.htm [access 04.04.2018].

[19] http://pkbwm.gov.pl/pl/prawo-i-dokumenty [access 05.04.2018].

[20] http://ums.gov.pl [access 06.04.2018].

[21] http://vizan.pl/pl/products/swibz/ [access 07.04.2018].

[22] http://www.umgdy.gov.pl/?attachment_id=8730 [access 04.04.2018].

[23] http://www.umgdy.gov.pl/pium/fundusze/podglad?kod=17nlkyirx2.3m4grzirx [access 03.04.2018].

[24] http://www.umsl.gov.pl [access 03.04.2018].

[25] https://www.nid.pl/pl [access 03.04.2018].

\section{FUNKCJONOWANIE PHI-CS (POLISH HARBOURS INFORMATION \& CONTROL SYSTEM) ORAZ SYSTEMU WYMIANY INFORMACJI I BEZPIECZEŃSTWA ŻEGLUGI W KRAJOWYM SYSTEMIE BEZPIECZEŃSTWA MORSKIEGO}

\section{STRESZCZENIE}

Zwiększenie bezpieczeństwa na polskich obszarach morskich jest nie tylko priorytetem administracji morskiej, ale wszystkich użytkowników tej strefy. W artykule przedstawiono zarówno ogólne założenia realizacji Krajowego Systemu Bezpieczeństwa Morskiego, jak i jego poszczególne elementy. Zawarto szczegółowe informacje systemu PHI-CS oraz systemu wymiany informacji i bezpieczeństwa żeglugi. Podjęto próbę zbadania zakresu modernizacji systemu wymiany informacji i bezpieczeństwa żeglugi. Opisano następujące elementy: krajowy system Safe Sea Net, zasady rejestracji pasażerów, bazy danych, połączenia teleinformatyczne.

Słowa kluczowe:

NMSS, system Safe Sea Net, PHI-CS, system wymiany informacji i bezpieczeństwa żeglugi.

Article history

Received: $\quad 25.05 .2018$

Reviewed: 09.09 .2018

Revised: $\quad 24.09 .2018$

Accepted: $\quad 25.09 .2018$ 